\title{
PROSPECTS FOR THE IMPLEMENTATION OF TRANSITIONAL JUSTICE IN UKRAINE
}

\author{
Chubinidze, Oleksandra \\ Chair of International Law - Taras Shevchenko National University of Kyiv - Kyiv, Ukraine. \\ Correspondence to (olexandra.chubinidze.fellow@gmail.com)
}

\section{COPYRIGHT NOTICE:}

(C) 2021 by author. Licensee ERUDITUS. This article is an open access article distributed under the terms and conditions of the Creative Commons Attribution (CC BY) license (https://creativecommons.org/licenses/by/4.0/).

\section{CITE THIS PAPER:}

Chubinidze, Oleksandra (2021). "Prospects for the Implementation of Transitional Justice in Ukraine" Journal of Social Sciences: Transformations \& Transitions (JOSSTT) 1(02):07. DOI: https://doi.org/10.52459/josstt1271221

\begin{abstract}
The study examines the features of transitional justice. The author gives definitions and goals of this concept. As it was noted by the scientists Ovcharenko and Shcherbaniuk, transitional justice includes judicial and extrajudicial mechanisms, such as prosecution, compensation, truth commissions, institutional transformations, and a combination of the above. For the first time, the content, main elements, and mechanisms of transitional justice are described in detail, which is considered in the context of the simultaneous transformation of Ukrainian society from an authoritarian past to a democratic present and from military conflict to post-conflict. Referring to Arkadiy Bushchenko (2017) transitional justice, as a model of society's transition from authoritarian to democratic, and from armed conflict to post-conflict, is currently the most modern approach to solving the problems that Ukraine has been dealing with since the end of 2013. Therefore, given this understanding, there is a prospect of developing a national legal model for the implementation of the basic principles of transitional justice. With the ultimate goal of the process of reconciliation in society, the concept of transitional justice involves the simultaneous operation of the state in four areas: effective criminal prosecutions, reparations, institutional reforms, and official statement of historical truth.
\end{abstract}

\section{KEYWORDS}

Transitional Justice, Human Rights Violations, Implementation, Judicial \& Extrajudicial Mechanisms 


\section{INTRODUCTION}

Every day, we observe violations of human rights, which are the most important values enshrined in international law, and these violations constitute crimes against international law. Ukraine is also experiencing a similar situation. During the aggravation of Ukrainian-Russian relations, the issue of responsibility of the parties to the conflict for crimes is very important. The practice of post-conflict settlement of different states shows the need to apply the concept of transitional justice to convict war criminals.

\section{METHODOLOGY}

This research is based on the conceptual approach of John Rawls (1980) who presents an overview of the field of transitional justice:

What justifies a conception of justice is not its being true to an order antecedent and given to us, but its congruence with our deeper understanding of ourselves and our aspirations, and our realization that, given our history and the traditions embedded in our public life, it is the most reasonable doctrine to us". ( Rawls, 1980: 519)

The methodological basis of this study includes general scientific and special legal research methods. Among the general scientific methods of research have been used philosophical, dialectical, synergetic, induction and deduction, typology, materialist, and empirical methods, and from the special legal research ones, the following methods including the method of complex analysis, which reveals the prospect of enshrining this concept in the legislation of Ukraine, and the formal-logical method to develop a unified approach to national regulations concerning the conditions, grounds, and subjects of application of transitional justice were applied.

\section{RESEARCH}

The International Center for Transitional Justice defines this term as "a set of ways to address the transition from a regime that tolerated mass violations of human rights to democracy." (ICTJ, 2009: 1).

Transitional justice consists of judicial and extrajudicial mechanisms, redress of human rights violations. It serves as a political tool for the transition from violence to stability in society. There is no ideal model for the application of transitional justice, so the Ukrainian model will need to be tailored to our situation. One of the central elements of transitional justice is criminal justice, aimed at prosecuting war criminals, establishing the truth, and rehabilitating victims of conflict (Ovcharenko, Shcherbaniuk, 2017: 262). 
The main goal of transitional justice is to end impunity and establish the rule of law in a democratic government. Transitional justice creates an atmosphere in which respect for human rights is a core value and accountability is a key goal. Transitional justice seeks to address the destructive and painful legacies of mass human rights violations. It involves mechanisms and processes such as truth-telling, criminal prosecutions, reparations, memorialization, traditional justice, cultural interventions, vetting, and institutional reform. The application of transitional justice is often more effective with a combination of mechanisms, to enable greater innovation and a comprehensive approach that evolves over time (Haider, 2016).

There have been few attempts both to theorize the concept of transitional justice itself because, the field of transitional justice is extremely heterogeneous; it is a relatively young field driven by practice; the concept of transitional justice appears to be continually in motion, etc. (Buckley-Zistel, Beck, Braun, Mieth, 2014). However, there is still no single document in international law on the concept of transitional justice. This creates a situation where there is no unified approach to its application by national courts. In our opinion, the International Law Commission should start work on the creation of such an international legal act, as transitional justice is increasingly used, while its use is complicated by the lack of a unified approach. The universal document must include among the mandatory provisions the definition of transitional justice, the grounds, and principles of its application, its types, etc.

With regard to such sources of international law as soft law, the concept of transitional justice is presented in the following documents:

- UN Resolution, A / RES / 60/147, 2006 "Basic Principles and Guidelines for the Right to Protection and Compensation to Victims of Gross Violations of International Human Rights Law and Serious Violations of International Humanitarian Law".

- UN Resolution, A / HRC / RES / 12/11, 2009 "Human Rights and Transitional Justice".

- UN Resolution, A / HRC / RES / 12/12, 2009 "Right to the Truth".

- "Fundamentals of EU policy to support transitional justice", 16 November 2015.

- UN Resolution, A / 68 / L.39, 2014, 68/262 of March 27, 2014 "Territorial Integrity of Ukraine".

- UN Resolution 71/205 of 19 December 2016 "On the situation of human rights in the Autonomous Republic of Crimea and the city of Sevastopol (Ukraine)".

- UN Resolution 72/190 of 19 December 2017 "On the situation of human rights in the Autonomous Republic of Crimea and the city of Sevastopol (Ukraine)" (OHCHR, 2009).

The first and ultimate goal of transitional justice for Ukrainian society in the context of armed conflict is access to justice, minimization of impunity, guarantees of non-repetition, finding ways of social unity and reconciliation. The first goal for its implementation is to bring the perpetrators to justice. It is 
achieved through improved legislation, judicial and investigative practice. The tasks for Ukraine at this stage should be:

- Analysis of the application of transitional justice in other countries: features, results, and risks.

- Analysis of national legislation, assessment of risks and prospects for the formation of the Ukrainian model of transitional justice.

- Formation of legislative and public initiatives in the field of implementation of mechanisms and principles of justice in transition.

- Coordination of the activities of the Office of General Prosecutor, State Security Service of Ukraine, Ministry of Internal Affairs of Ukraine in the investigation of crimes committed in the conflict zone.

- Development of procedures for attracting foreign judges, introduction of hybrid judicial mechanisms.

- Ensuring that all trials comply with international standards of due process, fairness, and impartiality.

- Improving judicial statistics in order to distinguish criminal proceedings for acts committed in the context of armed conflict.

- Defining the principles of political responsibility, which has two components: moral and political, political and legal.

- Development and implementation of effective programs for the protection of witnesses to a crime.

- Introduction of effective mechanisms for searching for persons.

The next goal is to compensate the victims of conflicts. It is achieved through material compensation for damage. This requires:

- Creation of a national register of damaged real estate, finding out the real amount of material and intangible losses.

- Development of criteria and introduction of a differentiated level of material compensation.

- Establishment of national mechanisms for compensation of victims, payment of compensation for physical and moral damages.

- Determining the level of compensation already made and payments.

- Compensation for damaged/lost property.

- Development of models of compensation for lost opportunities, including in the field of employment, education, and receiving social benefits.

- Social protection, employment, and reintegration of internally displaced persons. 
- Compensation for legal or expert assistance.

- A clear procedure for calculating the amount of compensation and priority of payments, based on the principles of transparency, voluntariness, openness, public participation, appropriateness of the degree of damage, proportionality, fairness, interagency coordination to prevent unjustified payments.

- Organization of state aid in the return, identification, and reburial of bodies.

- Providing scholarships to victims and their families.

- Establishment of a fund to compensate for the costs of medicines and medical care, as well as psychological and social services.

The third goal is the right to know the truth. It can be achieved by documenting events related to the armed conflict. Its tasks should be:

- Development and implementation at the national level of common approaches in the field of documenting human rights violations during armed conflicts.

- Organization of objective and unbiased documentary reconstruction of events.

- Formation of a national archive of photo and video documents of the conflict, registers of documents issued by authorities and officials of the administration of the Russian Federation, and by enterprises, institutions and organizations of the territories which are referred by Ukrainian authorities to as "temporarily occupied territories by Russia", received at the disposal of public authorities, local governments, persons authorized to perform state functions.

- Use of data from these archives and registers to investigate the restoration of historical truth.

- Collection of information from open sources regarding the participants in the armed conflict, potential human rights violations in the area of the armed conflict.

- Ensuring the participation of various parties in the documentation process, promoting openness, reconciling positions and information through dialogue meetings.

The last goal is to guarantee that the conflict will not recur, in particular through institutional reforms. It may be achieved by reforming the activities of the authorities. To do this, the following must be done:

- Development of a national strategy for the integration of the territories referred to as "temporarily not controlled" by the Ukrainian authorities, ensuring compliance with the rights of internally displaced persons in these territories.

- Bringing the legislation of Ukraine in line with the norms and standards of international humanitarian law, international criminal law, including the ratification of the Rome Statute of the International Criminal Court. 
- Reforming the law enforcement and judicial systems with a focus on the possible introduction of so-called hybrid judicial mechanisms.

- Reforming the civil security sector, developing state policy to protect the right to life of the population during military and emergency situations.

- Carrying out legal examination of laws and other normative legal acts in order to identify norms that contain risks of gross violations of international humanitarian law.

- Strengthening the independence of the judiciary.

- Improving the principles of information security of Ukraine with a balance between ensuring freedom of speech and combating the propaganda of war and hate speech.

- Formation of information and educational policies of the state taking into account the right to truth and learning the lessons of armed conflict, debatable aspects of reconciliation, and nonrecurrence of armed conflict.

- Carrying out lustration activities based on the presumption of innocence, ensuring the right to protection, the principles of individual responsibility, a clear delineation of the functions and objectives of lustration.

- Examination of civil servants or candidates to determine whether they have been involved in human rights violations.

- Introduction of the standard of information openness in the activities of self-government bodies and military-civil administrations for communities in Donetsk and Luhansk oblasts.

- Development and implementation of the National Program of Tourism and Cultural Exchange (East-West).

- Introduction of the National Mechanism of Academic Exchanges for students of higher educational institutions and students of higher degrees of secondary education institutions, scientific and pedagogical staff within Ukraine between educational institutions from different regions.

The Constitution of Ukraine provides for the administration of justice in Ukraine exclusively by courts. One of the guarantees of this principle is the rule that the takeover of court functions, illegal influence on its holders entail legal liability established by law (Constitution of Ukraine, art. 124). The creation of special or extraordinary courts is not allowed. In this regard, the conceptual framework for the implementation of transitional justice elements in the national criminal justice system should be developed. The purpose of this phenomenon is to ensure accountability, justice, and reconciliation. In this regard, the above-mentioned processes and mechanisms include prosecution, redress, truth-telling, institutional reform, review, and termination of criminal cases. 
There is no ideal model for the successful application of transitional justice, so mechanisms need to be carefully planned and adapted to the situation in a particular country. The task of transitional justice today is to adapt the current model of criminal justice bodies to the challenges and threats posed by hostilities in eastern Ukraine, to restructure the judiciary and law enforcement agencies to ensure judicial protection of victims of conflict and post-conflict situations, and to create new procedures and bodies, which could promptly and efficiently consider and resolve relevant categories of cases (Ovcharenko, Scherbaniuk 2017: 312).

We hold the position that the draft Law of Ukraine concerning transitional justice should contain the following provisions:

- compensation for damage and restoration of violated rights of victims of armed conflict;

- establishing the historical truth of what a separate institute or body specially created by the Cabinet of Ministers of Ukraine can do;

- Prosecution of perpetrators of war crimes, crimes against humanity, and gross violations of human rights, including through universal jurisdiction.

A distinction must also be made between moral and political responsibility in the form of public condemnation and political and legal responsibility (from fines to imprisonment). Political responsibility in both cases involves removal from office - lustration.

In addition to the consistent implementation of criminal justice, programs, further mechanisms, and measures to restore the rights of victims of conflict (restitution), which imposes on the state the relevant positive obligations, are also appropriate. At the same time, it is often advisable to use elements of transitional justice in its broadest sense. The peculiarity of the legal relationship in the framework of transitional justice is the role that should belong to the victims of crime, which deserves special attention both morally and politically, and pragmatically. In turn, restitution should include, in addition to "material" measures, mechanisms for the provision of services and restoration of rights, including the restoration of liberty, the ability to enjoy all human rights, the restoration of identity documents, marital status, and citizenship. The state should, and in a number of situations it is absolutely necessary, include restitution in its practice and legislation, and it should ensure its victims the implementation of it.

Observers of transitional justice application, such as Makau W. Mutua (2000) emphasized the difficulties of achieving actual justice through trials. In 1994, he argued that "International tribunal established in Rwanda serves to deflect responsibility, to assuage the consciences of states which were unwilling to stop the genocide...”. Lyal S. Sunga (2011:243) has argued that unless truth commissions are set up and conducted according to international criminal law, they risk undermining criminal prosecutions. He contends that this 
risk is particularly pronounced where truth commissions employ amnesties and especially blanket amnesties to pardon perpetrators of serious crimes.

The Ukrainian authorities must take the necessary steps to move from an armed conflict to a postconflict state. These steps should include:

- Making the necessary efforts to introduce transitional justice mechanisms in the activities of law enforcement and judicial bodies of Ukraine. Direct expertise for the formation of national truth-telling mechanisms aimed at reconciliation and non-infliction of additional trauma to victims of conflict (centralized database, joint work of government and non-governmental sector, documentary reconstruction of events).

- Assessing the existence of elements of transitional justice implemented in the modern activities of the Ukrainian authorities, as well as assess the resources and programs that may be involved in their further development in the domestic policy.

- Continuing to reform the law enforcement and judicial systems with a focus on the possible introduction of so-called hybrid judicial mechanisms, in particular, hybrid courts with a statutory procedure for involving foreign judges.

- Identifying at the level of law enforcement and judicial systems the need for common approaches to the identification of all victims of armed conflicts, providing them with effective compensatory remedies, restoration of their rights and freedoms in accordance with international law.

- Conducting a national discussion on civil security sector reform; developing appropriate policies and strategies to protect the right to life of the population during military and emergency situations.

- Strengthening the capacity of Ukrainian professionals working in the field of documentation and investigation of war crimes and violations of international humanitarian law, through specialized educational programs.

- Accelerating the development of legal mechanisms for the exchange of prisoners, the recording of cases of shelling of civilian objects, a transparent mechanism for determining and distributing compensation for damaged and lost property. (Butsko, 2019)

\section{RESULTS}

Summarizing the essence of transitional justice, it's clear that each state faces with own problems causing the need to implement the concept of transitional justice, where do not exist general and uniform recipes for all states. Thus, Ukraine needs to study and consider the experience gained by the world community, which after adapting to national realities will allow our country to overcome the negative 
consequences of, as referred by Ukrainian authorities "occupation of Ukrainian territories" and create the best conditions for their reintegration. Human rights activists emphasize that the effective components of the concept of transitional justice only in combination, and the implementation of all strategic goals and objectives will achieve the ultimate goal of the national strategy of transitional justice. The main issue is that the state leadership has enough political will, despite the understanding that this is a very difficult path.

The introduction of transitional justice in Ukraine should solve a twofold task: to help resolve the acute social conflict in the country and apply effective tools to compensate all victims of crime, as well as to promote a new, independent, self-sufficient criminal justice system capable of socially effective resolution, but also to meet the need of citizens for justice, ensuring the application of the rule of law in practice.

Transitional justice shifts the emphasis from the retributive (punitive) dimension of justice, which focuses on bringing perpetrators to justice, to the restorative dimension, which focuses on the rehabilitation and restoration of human dignity. At the same time, the model of transitional justice highlights the essence and purpose of justice as one designed to enable the peaceful coexistence of people.

To date, the provisions of Article 124 of the Constitution of Ukraine prohibits the establishment of special and extraordinary courts, so they block the introduction of some models of transitional justice adopted in world practice (in particular, the creation of so-called "hybrid courts", the introduction of international courts in Ukraine).

FUNDING: The author did not receive any external funding.

CONFLICT OF INTEREST: The author declares no conflicts of interest.

\section{DISCLAIMER}

The statements, opinions, conclusions, results, and data contained in the articles are solely those of the individual authors and contributors and not of the publisher and editors. ERUDITUS stays neutral with regard to religious and/or political issues, as well as jurisdictional claims, and disclaim any responsibility concerning any particular interpretation, perception, feel of offense, insults and/or indignation arising out of published articles written by authors. 


\section{REFERENCES}

1. Buckley-Zistel S., Beck T. K., Braun C., Mieth F. (2014). Transitional Justice Theories. Routledge. ISBN: 978-0-203-46573-8 (ebk). Available at: https://corteidh.or.cr/tablas/r32526.pdf

2. Butsko D. (2019). After the war: what will be the transitional justice. Available at:https://lb.ua/news/2019/11/14/442228 pislya_viyni_yakim_bude_perehidne.html

3. Constitution of Ukraine, art 124. Available at: https://rm.coe.int/constitution-ofukraine/168071f58b

4. Haider, H. (2016). Transitional justice: Topic guide. Birmingham, UK: GSDRC, University of Birmingham. Available at: https://gsdrc.org/wpcontent/uploads/2016/08/TransitionalJustice_GSDRC.pdf

5. ICTJ - International Center for Transitional Justice (2009). "What is Transitional Justice?". Available at: https://www.ictj.org/about/transitional-justice

6. Mutua M. W. (2016). Human Rights Standards: Hegemony, Law, and Politics. SUNY Press. ISBN 978-1-4384-5939-4

7. Ovcharenko O., Scherbaniuk O. (2017). Conceptual principles of introducing elements of transitional justice into the national criminal justice system in the context of European standards. In Bushchenko A.P., Gnatovsky M.M. (Eds.) Baseline study on the application of transitional justice in Ukraine: 261-326. Kyiv.: RUMES. ISBN 978-966-97584-3-9

8. Rawls, J. (1980) 'Kantian Constuctivism in Moral Theory', Journal of Philosophy, 77 (9): 515-572. https://doi.org/10.2307/2025790

9. Rule of Law - Transitional Justice. The Office of the High Commissioner for Human Rights. Available at: https://www.ohchr.org/EN/Issues/RuleOfLaw/Pages/TransitionalJustice.aspx

10. Sunga L. S. (2011) Commentary on Judgement of the ICTR's Case of Prosecutor v. Zigiranyirazo, 32 Annotated Leading Cases of International Criminal Tribunals. 240-258. 